\title{
Экспертиза
}

ШАТИЛОВ Александр Борисович - кандидат политических наук, доцент; декан факультета социальных наук и массовых коммуникаций, профессор департамента политологии Финансового университета при Правительстве РФ (125993, Россия, г. Москва, Ленинградский пр-кт, 49; absh71@yandex.ru)

\section{ИНОСТРАННЫЕ СТУДЕНТЫ И РОССИЙСКАЯ ПОЛИТИЧЕСКАЯ ПОВЕСТКА: СПОСОБЫ АДАПТАЦИИ}

\begin{abstract}
Аннотация. Статья посвящена анализу информационно-политической стороны академической мобильности и политических аспектов работы с иностранными студентами как в России, так и в ведущих зарубежных странах. Автор считает, что Российской Федерации требуется не только механически привлекать «внешних» студентов на обучение, но также способствовать их политической социализации и доносить до них российскую точку зрения по актуальным вопросам политики, идеологии, экономики. При этом важно действовать максимально аккуратно и деликатно, чтобы не спровоцировать обвинения в «пропагандистской обработке» студентов. Кроме того, имеет смысл проводить их последовательную и поэтапную социализацию, в обеспечении которой должны принять участие не только вузы, но также органы государственной власти и управления РФ и общественные организации.
\end{abstract}

Ключевые слова: академическая мобильность, национальные интересы, информационная политика, иностранные студенты, политическая социализация, политическая повестка

$\mathrm{B}^{\mathrm{H}}$ начале XXI в. с восстановлением относительного баланса сил мировых держав жесткая и прямолинейная составляющая внешней политики отходит на второй план, а на первый выходит принцип soft power, предполагающий «мягкое» воздействие на оппонентов (а иногда и союзников) с целью обеспечения своих национальных интересов. При этом одним из направлений soft power является академическая дипломатия, ориентированная на следующие задачи:

- создание актуального имиджа культурной, гуманитарно-гуманистической и образованной страны, готовой в альтруистических целях способствовать просвещению человечества, особенно его «отстающей» части в лице государств третьего мира;

- формирование пула агентов влияния из числа выпускников-иностранцев и приглашенных профессоров;

- донесение до мировой общественности через академическую сферу не только своих достижений в области образования и науки, но также своей позиции по важнейшим вопросам политической, социальной и экономической повестки;

- установление неформального взаимодействия с другими странами на гуманитарной основе;

- отбор и рекрутирование преподавательских и научных кадров из числа наиболее перспективных иностранцев.

В полной мере эти 5 позиций отражены в академической мобильности лишь шести государств мира (США, КНР, Российская Федерация, Великобритания, Германия, Франция). Остальные топовые участники конкуренции на глобальном образовательном рынке (например, Австралия или Япония) реализуют не все направления академической soft power. Так, скажем, Австралии, внешняя политика которой во многом вписана в международный курс «коллективного Запада», нет нужды разрабатывать собственную политическую повестку и тем более транслировать ее вовне. 
Однако для России, напротив, последнее обстоятельство весьма важно. Еще со времен «мюнхенской речи» В.В. Путина 2007 г., и особенно после 2014 г. наша страна находится в остром геополитическом и идейно-мировоззренческом конфликте с Западом. В ответ на попытки российского руководства обеспечить свой суверенитет США и их союзники, обеспокоенные появлением нового-старого антагониста, предприняли жесткое и практически тотальное наступление на позиции нашей страны по различным трекам. В частности, с учетом своего доминирования в мировом информационном пространстве Запад попытался лишить Россию возможности доносить свое альтернативное мнение до зарубежной аудитории. В этом плане можно отметить и максимальное ограничение деятельности российских СМИ на иностранных информационных площадках, и последовательную дискредитацию РФ как «государства несвободы» при посредничестве «институтов гражданского общества» (правозащитных, экологических, антидопинговых, антикоррупционных и пр. организаций), и откровенное искажение «неудобной» позиции нашей страны в сообщениях ведущих западных массмедиа. «Навязываемая нам и, в общем-то, всему миру евро-атлантическим сообществом информационное противостояние достигло на сегодняшний день весьма печальных показателей - хочется, конечно, сказать, наивысшей точки, но боюсь это произнести, потому что нет пределов их черной креативности. Можно сказать, что на информационном направлении мы находимся, конечно, в одной из нижних точек наших отношений с Западом со времен холодной войны», - так оценивает действия Запада официальный представитель МИДа России Мария Захарова ${ }^{1}$.

Такая откровенная ангажированность и односторонность информационной политики Запада требует от руководства России поиска новых, нестандартных вариантов и путей донесения до международной общественности собственной трактовки злободневных политических и экономических вопросов.

И в этом плане вполне перспективной представляется культурная, спортивная и академическая дипломатия, особенно последняя.

На данный момент РФ сумела не только сохранить привлекательность своей образовательной и научной модели, но даже расширить академические контакты с внешней средой [Расторгуев, Волхонская 2020]. В этом плане показательна статистика: численность студентов из-за рубежа в российских вузах с 2010 уч. г. по 2019 уч. г. увеличилась с 153 тыс. до 297,9 тыс. чел. ${ }^{2}$ При этом значительная часть из них (15 тыс.) уже сейчас учатся по квоте правительства России, а к 2022 г. квота возрастет до 23 тыс. ${ }^{3}$ Более того, наша страна после провальных 1990-х гг. вновь становится одним из притягательных образовательных центров мира. В частности, по данным Института статистики ЮНЕСКО, в настоящее время она занимает 6-е место по числу иностранных учащихся ${ }^{4}$. Кроме того, российские ученые активно развивают партнерство с зарубежными коллегами, встраиваются в международные индексы цитиро-

1 Захарова оценила отношения России и Запада на информационном направлении. - РИА Новости. Доступ: https://ria.ru/20200924/zapad-1577708644.html (проверено 17.11.2020).

2 Число иностранных студентов в российских вузах за 10 лет увеличилось почти вдвое. TACC. Доступ: https://nauka.tass.ru/nauka/7562175 (проверено 02.10.2020).

3 Иностранцев, которые учатся в России по квотам, станет на три тысячи больше. Российская газета. Доступ: https://rg.ru/2020/07/16/inostrancev-kotorye-uchatsia-v-rossii-pokvotam-stanet-na-tri-tysiachi-bolshe.html (проверено 14.10.2020).

4 Статистика согласно UNESCO (United Nations Educational, Scientific, Cultural Organization), OECD (Organisation for Economic Co-operation and Development) и GeoNames. - UNIPAGE. Доступ: https://www.unipage.net/ru/student_statistics (проверено 14.10.2020). 
вания, реализуют статусные совместные проекты. Интенсивно развиваются также контакты российских и зарубежных вузов по самым разным направлениям (программы двойного диплома, программы включенного обучения, программы «приглашенный профессор» и др.).

Все это создает возможности для «косвенной» политической и идеологической работы с иностранными контрагентами, особенно студенческой аудиторией [Расторгуев 2019]. Последние являются достаточно восприимчивыми в плане донесения российской политической, мировоззренческой и социальноэкономической повестки в силу следующих обстоятельств:

- вследствие юного возраста и несформированности жесткой антироссийской позиции;

- в результате юношеского максимализма, нежелания следовать общепринятой на Западе антироссийской конъюнктуре;

- из-за временного отрыва от западного информационно-агитационного влияния;

- в силу «адаптирующего» влияния российских студентов и преподавателей;

- из-за наличия доброжелательной атмосферы, традиционно складывающейся в вузе вокруг иностранных студентов;

- вследствие опровержения многих мифов и фейков о России в ходе непосредственного пребывания на ее территории.

Однако информационно-разъяснительная работа с представителями зарубежной молодежи требует известного мастерства и аккуратности, поскольку прямолинейное и догматичное навязывание ей российской точки зрения по актуальным политическим вопросам может спровоцировать у нее либо скепсис по отношению к «путинской пропаганде», либо вообще враждебность и недоверие к нашей стране и ее политическим институтам.

Думается, что процесс «пророссийской» политической социализации иностранных студентов должен носить постепенный, но последовательный характер. В частности, можно выделить ряд этапов такой социализации.

Первый этап - адаптационный. Он охватывает (если брать бакалавриат) первые три семестра обучения. На данном этапе требуется обеспечить максимальное включение иностранных студентов в российскую академическую среду и решить вопросы их культурной адаптации и социального обеспечения. При этом политическое и идеологическое воздействие должно быть минимальным, скорее требуется сосредоточиться на вовлечении зарубежных первокурсников в вузовскую среду и студенческую жизнь. Тем не менее параллельно можно знакомить их с культурой и историей России, основами ее политической системы, обычаями и традициями в рамках дисциплин общеуниверситетского блока, не расставляя откровенных политических и идеологических акцентов. При этом требуется очень живое и заинтересованное общение с аудиторией иностранных студентов, поскольку формальный подход «уже на старте обнуляет все даже самые эффективные методики и разработки» [Салин 2020: 17].

Второй этап (2-3-й курс бакалавриата) предполагает «погружение» иностранного студента в российскую политическую и социально-экономическую повестку через профильные образовательные дисциплины, а также через участие иностранных студентов в мероприятиях политической социализации (встречи с представителями российской элиты и статусными персонами из экспертного сообщества, приглашение иностранных студентов на российские молодежные форумы и конференции, включение их в волонтерские проекты и пр.).

Третий этап (4-й курс) является наиболее важным, поскольку он предше- 
ствует выпуску обучающегося и его окончательному становлению в качестве самостоятельной личности и молодого специалиста. Здесь требуется работа по двум направлениям. С одной стороны, необходимо «зацепить» иностранного студента в академическом плане (например, закрепить за ним в качестве научного руководителя известного и популярного ученого или способствовать его первым публикациям в авторитетных научных изданиях). С другой стороны, помимо вуза, требуется подключение к его политической социализации статусных государственных и общественных структур. Например, для создания приятного «послевкусия» от пребывания иностранных студентов в России имело бы смысл проводить для них на федеральном уровне специальный выпускной бал с участием первых лиц государства.

Огромное значение имеет также сохранение тесного взаимодействия с иностранными выпускниками и после окончания их обучения, в т.ч. в плане их политической социализации и информирования о политических и социальноэкономических процессах в нашей стране. Это достигается, во-первых, за счет их интеграции в различные клубы выпускников с предоставлением определенных бонусов и дополнительных возможностей; во-вторых, за счет подписки их на безвозмездной основе на новостные ленты ведущих российских информационных агентств; в-третьих, за счет периодического приглашения их на мероприятия alma mater в Россию (опять же с предоставлением определенных льгот, например бесплатного проживания в общежитии «родного университета»).

Такая комплексная работа позволит, с одной стороны, сформировать у иностранного студента позитивное отношение к нашей стране и нашему народу, а с другой - приобщит его к российской политической повестке, в т.ч. транслируемой официальными СМИ РФ.

Статья подготовлена по результатам исследований, выполненныхза счет бюджетныхсредств погосударственному заданию Финуниверситету.

\section{Список литературы}

Расторгуев С.В. 2019. Обучение иностранных студентов в России: политические, экономические, социальные факторы. - Власть. 2019. Т. 27. № 4. С. 32-39.

Расторгуев С.В., Волхонская 3.И. 2020. Методология исследования общественно-политических установок иностранных студентов. - Гуманитарные науки. Вестник Финансового университета. Т. 10. № 4. С. 6-13.

Салин П.Б. 2020. Ключевые проблемы политической социализации обучающихся в РФ иностранных студентов. - Гуманитарные науки. Вестник Финансового университета. Т. 10. № 4(46). С. 14-18.

\section{FOREIGN STUDENTS AND THE RUSSIAN POLITICAL AGENDA: WAYS OF ADAPTATION}


that the Russian Federation needs not only to attract foreign students to our studies mechanically, but also to promote their political socialization and convey to them the Russian point of view on topical issues of politics, ideology, and economics. At the same time, it is important to act as carefully and delicately as possible so as not to provoke accusations of propaganda processing of students. In addition, it makes sense to carry out their consistent and gradual socialization, in the provision of which not only universities, but also government and administrative bodies of the Russian Federation and public organizations should take part.

Keywords: academic mobility, national interests, information policy, foreign students, political socialization, political agenda

АРШИН Константин Валерьевич - ученый секретарь Федерального исследовательского центра картофеля им. А.Г. Лорха (140051, Россия, Московская обл., г. Любериы, пос. Красково, ул. Лорха, 23В; Kosta-10@yandex.ru)

\title{
ФАКТОР МИГРАЦИИ В РОСТЕ РЕЛИГИОЗНОЙ КОНФЛИКТОГЕННОСТИ (НА ПРИМЕРЕ ЕВРОПЫ): СОЦИАЛЬНО-ФИЛОСОФСКИЙ ПОДХОД
}

\begin{abstract}
Аннотация. За последние годы в мире наблюдается не менее десятка конфликтов, которые либо ведутся представителями различных конфессий, либо осмысливаются как конфликты на религиозной почве. Это и гражданская война в Йемене, и конфликты в индийских штатах - Ассаме, Нагаленде и Манипуре, и конфликт в Мьянме между араканцами-буддистами и мусульманами-рохинджа. Часть этих конфликтов осмысливаются в качестве столкновения коренного населения и мигрантов. Однако и религиозный фактор играет в них значимую роль. В условиях нарастающей миграционной активности можно ожидать нарастания межрелигиозной конфликтности, в основе которой будет лежать миграционный фактор. Решение указанной проблемы видится в реализации проекта «конституционного патриотизма».
\end{abstract}

Ключевые слова: миграция, конфессия, конфликт, ислам, Европа, США, цивилизация, радикализм, идентичность

$\mathrm{B}$ 1996 г. американский политолог Самюэль Хантингтон в своей книге «Столкновение цивилизаций» выдвинул идею, согласно которой современный миропорядок поделен между 9 крупными наднациональными образованиями - цивилизациями [Хантингтон 2003]. В основе указанного разделения лежит господствующая в каждой из цивилизаций культурная доминанта, которая, в конечном счете, соотносится с той религией, которую исповедует большинство населения стран, объединенных Хантингтоном в цивилизацию. Так, в православную цивилизацию американский политолог включил непосредственно Российскую Федерацию, а также Беларусь и Украину; в исламскую цивилизацию - государства, население которых исповедует ислам (вне зависимости от того, какую ветвь); в конфуцианскую цивилизацию - Китай; в западную цивилизацию - государства Европы, а также страны переселенческого капитализма (США, Канада, Австралия, Новая Зеландия). Важнейшим в схеме Хантингтона был тезис о несовместимости цивилизаций, их принципиальной конфликтности, что означает принципиальную конфликтность культур, а значит и лежащих в основе культур религий.

Для современного мира, в котором миграция огромных масс людей стала насущной потребностью, а значит, взаимодействие представителей различных 